\title{
Montréal Catholic School Teachers, International Unions, and Archbishop Bruchési: The Association de bien-être des instituteurs et institutrices de Montréal, 1919-20
}

\section{Geoffrey Ewen}

Recent publications show that early $20^{\text {th }}$ century Canadian teachers either shunned the American Federation of Teachers and its links to blue collar workers, refusing to do as American teachers had done, or, as Western Canadian Teachers' Associations did, moved on their own to bargain collectively. ${ }^{1}$ I propose to challenge these views by investigating teachers' collective identity as workers/professionals ${ }^{2}$ -asking why and when men and women teachers have shown solidarity with the labour movement ${ }^{3}$ - and considering the role of the Québec Catholic Church in shaping labour relations at a crucial juncture in Canadian labour history. ${ }^{4}$

On Friday 25 November 1920, Paul Bruchési, Archbishop of Montréal since 1897 , rose before a large crowd to declare that the city's underpaid Catholic school teachers demanded a wage increase and had a right to do so. His assembled audience burst into spontaneous applause. The Archbishop thus closed the first Semaine sociale, a week of lectures on the 1891 papal encyclical Rerum novarum ["On the Condition of the Working Classes"]. Bruchési's final words dealt with the union of Montréal's public Catholic school teachers, the Association de bien-être des instituteurs et institutrices de Montréal (ABE), then locked in bitter conflict with the Montréal Catholic School Commission. Despite his expressed sympathy, Bruchési went on to ask teachers to abandon organizing or collective bargaining

'Andrew Spaull, "Fields of Disappointment: The Writing of Teacher Union History in Canada," Historical Studies in Education 3, 1 (Spring 1991): 21-47. For the image of teachers in Western Canada see Tom Mitchell, “'We Must Stand Fast for the Sake of Our Profession': Teachers, Collective Bargaining and the Brandon School Crisis of 1922,"Joumal of Canadian Studies 26, 1 (Spring 1991): 82-99. Canadian teachers considered joining local trades councils much earlier. Alison Prentice showed that the Women Teachers' Association in Toronto briefly considered doing so as early as 1905 . Alison Prentice, "Themes in the History of the Toronto Women's Teachers' Association," in Paula Bourne, ed., Women's Paid and Unpaid Work: Historical and Contemporary Perspectives (Toronto: New Hogtown Press, 1985).

${ }^{2}$ On professionalism and proletarianization for members of another "semi-professional" occupation, see Kathryn McPherson, Bedside Matters. The Transformation of Canadian Nursing, 1900-1990 (Toronto/New York: Oxford University Press, 1996).

${ }^{3}$ Ruth Frager examines the issue of cooperation between men and women in the labour movement in Sweatshop Strife. Class, Ethnicity and Gender in the Jewish Labour Movement of Toronto, 1900-1939 (Toronto: University of Toronto Press, 1992).

'On the origins of the Catholic labour movement and for discussion of Archbishop Bruchési see Jacques Rouillard, Les syndicats nationaux au Québec de 1900 à 1930 (Québec: Presses de l'Université Laval, 1979). 
because, unlike private sector workers, they served the public and the nation. $\mathrm{He}$ left it unstated that a teacher union threatened the Québec Church's dominant role in education. ${ }^{5}$

Canadian teachers had occasionally formed unions or professional associations for collective bargaining between 1917 and 1921, some even going on strike, but most shunned any identification with organized labour. ${ }^{6}$ Teachers saw themselves as professionals socially superior to manual workers in private sector unions. ${ }^{7} \mathrm{~A}$ significant exception to these generalizations, the ABE aimed to broaden collective bargaining by recruiting intellectual workers in the public sector. ABE teachers embraced international unionization as the only way to improved salaries and job security. They affiliated with the American Federation of Teachers, an American Federation of Labor organization, and formed close ties to the local labour movement. ${ }^{8}$ In the post-War years unions, particularly those affiliated with the Montréal Trades and Labour Council, had a reputation for strength and combativeness, and teacher unionists needed solid allies as they confronted formidable opponents on the Commission.

Montréal's teachers unionized in the wake of far-reaching administrative changes to the city's school system. Montréal had annexed several surrounding municipalities and thereby 22 school boards by 1917, some no larger than a single parish, many heavily indebted. Rapid population growth meant serious overcrowding. Many parents had difficulty registering their children for school.'

Progressive middle class reformers pushed for school board amalgamation with centralized oversight. They hoped business-like management of Catholic public education would reduce costs and establish efficient administrative control over the teaching body, whose salaries made up the largest non-capital expense in the Commission's budget. Montréal's international unions had long since championed

${ }^{5}$ Le Devoir, 26 June 1920; On the Semaine sociale see Michael Oliver, The Passionate Debate: The Social and Political Ideas of Québec Nationalism 1920-1925 (Montréal: Véhicule Press, 1991), 68.

${ }^{6}$ For other teacher unions formed during the years 1916 to 1920 in Canada, see Ian McKay and Suzanne Morton, "The Maritimes: Expanding the Circle of Resistence," in Craig Heron, ed., The Workers' Revolt in Canada, 1917-1925 (Toronto: University of Toronto Press, 1998), 50, 57; and in Allan Seager and David Roth, "British Columbia and the Mining West: A Ghost of a Chance," ibid., 252.

'Spaull, "Fields of Disappointment," 25; Craig Heron, "National Contours: Solidarity and Fragmentation" in Heron, op. cit., 285.

${ }^{8}$ On the American Federation of Teachers and teacher unionism in the United States during this period, see Marjorie Murphy, Blackboard Unions. The AFT and the NEA, 1900-1980 (Ithaca and London: Cornell University Press, 1990), and Wayne Urban, Why Teachers Organized (Detroit: Wayne State University Press, 1992).

${ }^{9}$ For a discussion of the Montréal Catholic School Commission in this period see Ruby Heap, "L'Église, l'État et l'enseignement primaire public catholique au Québec, 1897-1920," Ph.D thesis, University of Montréal, 1986; and Ruby Heap, "Urbanisation et éducation: la centralisation scolaire à Montréal au début du XXe siècle," Historical Papers/Communications bistoriques, 1985, 132-55. 
compulsory attendance, textbook uniformity, school board amalgamation, an elected school board, and establishment of a provincial ministry of education. ${ }^{10}$

With capital and labour advocating parallel reforms, opposition to change came mainly from the Church, whose preëminent role in Catholic education was symbolized by the fact there was no provincial Minister of Education. "It was a decentralized system whose boards chose their own texts, requiring religious teaching orders to use texts approved by the Catholic committee. ${ }^{12}$ From parish priests through Montréal Archbishop Bruchési, the Church hierarchy condemned unification as a threat to local control, and opposed election of any Commission members. ${ }^{13}$

On 1 July 1917, 23 previously independent boards were incorporated into the Montréal Catholic School Commission's jurisdiction throughout Montréal and the suburban municipality of Maisonneuve. The amalgamated school board became the largest in Canada, with 160 schools and an enrolment of almost 75,000. During the 1919-20 school year, it employed 2,146 teachers. Over two-thirds of classrooms were staffed by members of the Church's teaching orders, some 581 brothers and 889 sisters. The 676 lay teachers- 333 men and 343 women - were mostly francophone. ${ }^{14}$

A central seven-member appointed board now controlled finances, including teachers' salaries; otherwise the city was divided into four districts with individual six-member boards responsible for hiring and pedagogical matters. Between 1917 and 1925, the Archbishop, the Provincial Government, and the City of Montréal each made one appointment to the central board, and two each to the district boards. Each district commission chose a representative (who could not be a district commissioner) to sit on the central board; one representative had to be a priest.

This redistribution of power increased the presence of laymen at the expense of the clergy. The Commission president, until then always a cleric, would hence-

\footnotetext{
${ }^{10}$ See the program of the Montréal Labor Party in Le Groupe de chercheurs de l'Université du Québec à Montréal sur l'histoire des travailleurs québécois, $L$ 'Action politique des ouvriers Québécois (fin du XIXe siècle à 1919), Montréal, 1976, 39-41; and the Labor Party's presentation before a provincial Royal Commission on education in 1911, ibid., 63-6. For the position of the Montréal Trades and Labour Council and the Québec provincial executive of the Trades and Labour Congress of Canada see Céline Bastien, "Les syndicats internationaux et les réformes scolaires au Québec (1900-1930)," unpublished M.A. Thesis, Université de Montréal, 1997.

"All of Québec's Catholic bishops sat on the Catholic public instruction committee along with an equal number of laymen, all prominent members of the bourgeoisie. Unlike the lay members, the bishops could designate a delegate to sit in their absence, ensuring their domination.

${ }^{12}$ Bastien, "Les syndicats internationaux," 40.

${ }^{13}$ Heap, “Urbanisation et éducation," 133, 138-40, 145.

${ }^{14}$ Wayne State University (WSU), Archives of Labor and Urban Affairs, American Federation of Teachers (AFT), Series VI, Box18, Local 130, Eudore Gobeil to F.G. Stecker, 6 March 1920; Anglophone students made up eight percent of the total student body; Robert Gagnon, Histoire de la Commission des écoles catholiques de Montréal: le développement d'un réseau d'écoles publiques en milieu urbain (Montréal: Boréal, 1996), 102, 120.
} 
forth be a layman, usually an experienced administrator from outside the Commission. Most importantly, the reform marked the beginning of a period when Commission presidents would be closely tied to the provincial government of the day: Judge Eugène Lafontaine, the first lay president, was a former Liberal MLA very close to Premier Lomer Gouin. Although the province retained control of school boards' property tax rates, clerics presided over three of the four district boards, and the president required the support of the Archbishop. ${ }^{\text {is }}$

The Commission had always had an appointed board, but residents of the annexed municipalities who had previously elected their school commissioners now found themselves disenfranchised. The new Act further distanced the Commission by barring Montréal's mayor and elected councillors. Progressive reformers accepted a completely appointed body as free from machine politics and the corruption of municipal political life, ${ }^{16}$ but the new Commission did not include a single representative of the working-class and lower-middle-class parents whose children attended its schools. It was dominated by French Canadian middle-class reformers, businessmen and professionals who sent their own sons and daughters to private Church-run institutions. Schools had a central role in defining French Canadian national identity, with Catholicism a core element of that identity.

Workers were occasionally given token representation on non-educational government bodies, but during the immediate post-war years, in view of the Montréal labour movement's support of far-reaching educational reform, government and Church officials opposed working class representation in educational governance. Consistent with the position of the provincial government, the Québec Catholic Church, and Catholic intellectuals alike, no women were appointed to the Commission or to any other body overseeing Catholic education. ${ }^{7}$

As even Bruchesi had admitted, teachers' chief motive for unionizing was to win better salaries. Teachers in other Canadian cities were much better paid, as were Montréal's Protestant teachers. Catholic teachers' earnings depended on sex, level of certification, sacerdotal status, length of service, and (men's) marital status, producing galling contrasts. For instance, in 1917 the starting salary for men was reduced from $\$ 700$ to $\$ 600$. By 1919 married men received a minimum of $\$ 1,000$ and a maximum of $\$ 1,400$ to $\$ 1,700$, depending on certification; for laywomen the minimum was $\$ 500$ and the maximum $\$ 600$ to $\$ 800$. Rampant inflation had severly

${ }^{15}$ Heap, "Urbanisation et éducation," 152; Renée Lescop-Beaudouin, "Une étude du Pouvoir officiel à la C.E.C.M. Les présidents de la Commission des Écoles catholiques de Montréal de 1846 à 1965," M.A. Thesis, Université de Montréal, 1967, 86-96, 116-25.

${ }^{16}$ Heap, "Urbanisation et éducation,"141-2, 153.

17Wendy Johnston, "L'école primaire supérieure et le high school publicà Montréal de 1920 à 1945," Ph. D. Thesis, Université de Montréal, 1991, 121; Heap, "Urbanisation et éducation," 153-4; Johnston, "L'école primaire supérieure," 407, 413; Susan Mann Trofimenkoff, "Henri

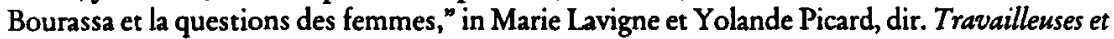
féministes. Les femmes dans la société québécoise (Montréal: Boréal Express, 1983), 293-306; Jennifer Stoddart, "Quand des gens de robe se penchent sur les droits des femmes: le cas de la commission Dorion, 1929-1931, in Ibid., 307-36. 
eroded teachers' standard of living. Many long-term employees earned far less than the maximum because increments were awarded arbitrarily. In 1919 the average for men, including principals, was $\$ 1,205$. At the Protestant School Board of Montréal, women's salaries ranged from $\$ 850$ to $\$ 1,250$ in 1919 . Those for men started at $\$ 1,000$ and could reach $\$ 2,700$ to $\$ 3,000$. Protestant teachers also enjoyed a better pension plan. ${ }^{18}$

Commission salaries were kept down partly because of a fiscal crisis in education. Already heavily in debt, the Commission was under pressure to build new schools to relieve overcrowding and provide more and better levels of instruction. The main source of revenue, municipal property taxes, seriously disadvantaged Catholic education, since Protestants were on the whole richer in property. Only the provincial government could raise taxes, and in a city where $80 \%$ of working class families were tenants, the Association des propriétaires opposed any tax increase. ${ }^{19}$

The proposed enlargement of the school system was attractive to teachers hoping for career advancement. As with teaching positions, access to promotions was limited by clerical teaching orders, although lay men and women could become principals. In 1915, 6 of 61 mixed or girls schools were run by laywomen, at a time when lay women constituted more than one quarter of the female teaching force. ${ }^{20}$

Teachers resented authoritarian treatment almost as much as they did limits to advancement. Provincial legislation permitted school boards to fire teachers, or to refuse to rehire them, without cause. Teachers charged school principals with using their powers in an arbitrary and abusive manner. They complained of nepotism, of political interference, of patronage in the allocation of promotions and of intimidation. Amalgamation and the institution of a two-tiered school board structure meant teachers faced a new layer of bureaucracy which distanced teachers from their employer. ${ }^{21}$

If some hoped for career advancement, most male teachers were concerned simply to keep their jobs. The Commission had maintained the practice of hiring men to teach boys and women to teach girls. But the idea of replacing the men who taught younger children in the first three years of school with women at

\footnotetext{
${ }^{18}$ Montréal Catholic School Commission (MCSC) Archives, Associations syndicales et autres, Association de bien-être des instituteurs et institutrices de Montréal 1919-1920, Factum. Respectueusement dedié a l'Honorable Premier Ministre Sir Lomer Gouin, nd. 2-4.

${ }^{19}$ Terry Copp. The Anatomy of Poverty: The Condition of the Working Class in Montréal, 1897-1929 (Montréal: McClelland and Stewart, 1974), 174, 63; La Patrie, 15 Octobre 1919.

${ }^{20}$ Ruby Heap, “Les femmes laiques au service de l'enseignement primaire public catholique à Montréal," Canadian Women Studies 7, 3 (Fall 1986): 55, 59.

${ }^{21}$ See the proposed collective agreement, Article 7 in MCSC, Associations syndicales et autres, Association du bien-être des instituteurs et institutrices de Montréal, Généralité, 1919 à 1920; La Patrie, 11, 22 December 1919; Université du Québec à Montréal Archives, Fonds de l'École Normale Jacques-Cartier, Correspondance avec divers particuliers et organismes, 1918-1921, Anonymous mimeograph, "Nos instituteurs ont-ils des griefs," nd.
} 
lower rates of pay had been under consideration for at least a year. This threatened the jobs of 238 of 333 laymen and prompted the male teachers to organize. ${ }^{22}$

Earlier teachers' organizations could not adequately promote teachers' material interests. From 1857, men teachers could belong to the Association des Instituteurs de la Circonscription de l'École Normale Jacques Cartier (AICÉNJC), a meek association led by school principals and senior administrators that organized pedagogical and social activities. Francophone women had the Association des institutrices du Québec (section Montréal), affiliated since 1907 to the Fédération nationale SaintJean-Baptiste. This gave them a link to middle class feminists; as a Catholic association, it was constrained. Chaplains were present at executive board and general membership meetings, Fédération leaders had to avoid offending teaching sisters who were also members, and the Church hierarchy refused to countenance women suffrage. Nonetheless it called for higher teacher salaries. Anglophone lay women teachers had an association by 1918 , but the Commission refused to recognize it or to grant it the privileges afforded to their francophone counterparts. ${ }^{23}$

Montréal Catholic school teachers first tried to set up a "Catholic union." During and after the First World War the Church promoted formation of a Catholic labour movement as an alternative to USA-based international unions. In October 1918 two men launched l'Union catholique des instituteurs de Montréal; within a month it had 300 members-almost the entire lay male teaching force. That the chaplain of the Catholic unions in Montréal, Abbé Edmour Hébert, addressed a meeting of the teachers on the principles and aims of the new movement suggests some Catholic union promoters welcomed a teacher union. A Catholic labour organization required diocesan approval, but Archbishop Bruchési issued a veto without explaining his reasons: "Une telle union, dans notre organisation scolaire actuelle, ne me parait aucunement opportune." There was no choice but dissolution. ${ }^{24}$

Male lay teachers then formed a comité des intérêts matériels within the older AICÉNJC. In September 1919, this new committee asked the Commission for an immediate across-the-board increase of $\$ 400$ for men and women, and an annual increase of $\$ 100$ rather than $\$ 50$. If rejected they wanted the issue referred to an arbitration board. They also asked for a response within a week. Far from the usual respectful submission, the language sounded like demands from a union.

\footnotetext{
${ }^{22}$ It was being discussed in 1918 when they first attempted to form a Catholic union.

${ }^{23}$ Pierre Dionne, "Une analyse historique de la Corporation des enseignants du Québec (1836-1968), "M.A. Thesis, Université Laval, 1969, 13, 17, 46; Marîse Thivierge, "Les institutrices laïques à l'école primaire catholique au Québec, de 1900 à 1964" Ph.D. Thesis, Université Laval, 1981, 280; MCSC Archives, District Centre, Délibérations, vol. 32, 9 December 1918, 264; Bureau Central, Délibérations, 27 May 1919.

${ }^{24}$ L'Enseignement primaire, December 1918, 254; Labor World, 7 December 1918; Archives de la Chancellerie de l'archevêché de Montréal (ACAM), Mgr. Bruchési lettre book, vol. 7,369, Mgr. Bruchési to M.N.E. Gobeil, 24 November 1918.
} 
The astonished commissioners balked at what Commission president Lafontaine described as a "menace impertinante. ${ }^{\text {"25 }}$

On 3 October 1919, some 400 Montréal lay Catholic school teachers met to form the Association de bien-être. By discreetly affiliating with the American Federation of Teachers, they could join the Montréal Trades and Labour Council and the Trades and Labour Congress of Canada. Fearing the reaction of the Board, and remembering Mgr. Bruchési's 1918 veto, a small group met secretly several times before calling a public meeting for all lay teachers. ${ }^{26}$ Québec workers contended they could be good Catholics and good international union members, and Catholic school teachers believed they had a right to organize without falling under suspicion of being anti-clerical or freethinkers. After all, some American Catholic bishops actively supported international union membership. Bruchési nonetheless denounced international unions as foreign bodies ${ }^{27}$ and $\mathrm{ABE}$ promoters, accepting their work would not receive clerical approval, simply contended Bruchési should not deal with their demands, ${ }^{28}$ as financial control rested principally in the hands of Commission laymen.

The ABE was organized by a core group of ten men and one women, including N. Eudore Gobeil, J.J. Fahey, H.G. Meloche, Antoine Maltais, and Mary Hoey. Gobeil and Meloche had been leaders of the Catholic union; Gobeil was also a member of the comité des intérêts matériels; Hoey was secretary of "The Montréal Catholic Lady Teachers' Association," which received Bruchési's blessing and a chaplain in February 1919. It was the same core group of organizers that requested an American Federation of Teachers charter. ${ }^{29}$

Although the $\mathrm{ABE}$ aimed to organize all teachers, impetus to join an international union came initially from men. By late November the ABE claimed 230 of 322 eligible men were members. Men held all the executive positions. Women organized an associate committee with a separate leadership. At first the male leadership's demands maintained the gender-based salary differential, but ABE women voted for equal pay, effectively making elimination of the differential a central union demand. The men quickly deferred: an end to wage discrimination would in any case remove the incentive to replace men with women in the earlier grades. An authentic alliance had been forged: leaders of the women's section

${ }^{25}$ L'Enseignement primaire, March 1919, 409-10; G. Bellefleur to Eugène Lafontaine, 22 September 1919 in MCSC Archives, Association syndical et autres, Association des instituteurs de la circonscription de l'école normale Jacques-Cartier, 1919; La Patrie, 2 October 1919.

${ }^{26}$ Thivierge, "Les institutrices laïques," 282.

${ }^{27}$ This was during a dock workers'strike in 1903. See Joseph Levitt, Henri Bourassa and the Golden Calf. The Social Program of the Nationalists of Québec, 1900-1914 (Ottawa: University of Ottawa Press, 1972), 100-1.

${ }^{28}$ La Patrie, 20 October 1919; Chartrand, Une certaine alliance: 60 ans...et après? (Montréal: Allience des professeurs de Montréal, 1980), 18.

${ }^{29}$ It was these eleven members who requested the charter. WSU Archives, AFT, Series VI, Box 18, Local 130, see the charter issued 7November 1919; ACAM, Mgr Bruchési lettrebook, vol. 7, 385, Mgr Bruchési to Miss M.T. Hoey, 10 February 1919. 
spoke regularly at $\mathrm{ABE}$ meetings and encouraged other women to join; male $\mathrm{ABE}$ leaders did not consider proposals without first discussing them with the women's section. By early December the Association claimed to represent a majority of female and male teachers: 451 men and women, anglophones and francophones. ${ }^{30}$

Montréal's Catholic teachers were remarkable in seeking direct links to the labour movement, joining the American Federation of Teachers. Established in 1916, the Federation received considerable financial and organizational support from American Federation of Labor president Samuel Gompers. By 1920 the Federation had 10,300 members in the United States. It encouraged ABE leaders to join the local labour council as this strategy had proven effective in American cities. Contact with Montréal labour leaders, however, predated the decision to join an international union. It was Aurèle Lacombe, the president of the Montréal Tramway Union, who wrote to the Federation supporting the request for affiliation. ${ }^{31}$

Membership in the Montréal Trades and Labour Council and legitimacy in the local international labour movement may have been the main reasons for joining the American Federation of Teachers. Teachers turned to the secular international unions because in the late war years and in 1919 they had won a number of important disputes. From 1916, there were more strikes, larger confrontations, and more success. During the war, a sense of injustice grew, as did a desire for more economic security and the post-war expectation of more democratic relations in society and on the shop floor. Membership now included workers with little previous experience in the labour movement and women, immigrants, and the less skilled were welcomed. ${ }^{32}$

Now at last, labour organization extended to include public sector workers, most notably municipal workers. Teachers noted the advantages won by recently organized public sector unions, and how they surmounted faced fierce opposition to their right to organize. In Montréal one dramatic confrontation was a two-day strike in November 1918 by municipal workers, including police and firefighters, against provincially-appointed trustees administering the city's financial affairs. The trustee had to make important concessions, as the unions won collective agreements. Montréal's municipal unions furthermore declared independence from religious authority in declining an offer from Archbishop Bruchési to mediate the dispute

${ }^{30}$ La Patrie, 11 October, 11, 17, 22, 28 November, 6, 11 December 1919.

${ }^{31}$ Urban, Why Teachers Organized, 134-5; Murphy, Blackboard Unions, 86, 99; wSU Archives, AFT, Series VI, Box 18, Local 130; FGS to Eudore Gobeil, 7 November 1919; Labor World, 7 August, 4 December 1920; wsU Archives, AFT, Series VI, Box 18, Local 130,A. Lacombe to Chas. B. Stillman, 5 November 1919.

${ }^{32}$ Craig Heron and Myer Siemiatycki, "The Great War, the State, and Working-Class Canada," in Craig Heron ed., The Workers' Revolt in Canada, 1917-1925, Toronto, University of Toronto Press, 1998, 11-42; Geoffrey Ewen, "Québec: Class and Ethnicity" in Heron, ed., Workers Revolt, 97-116. 
shortly before the strike. ${ }^{33}$ If police and firefighters could organize and bargain collectively, then why should teachers not have the same rights?

There may be another reason why Catholic teachers turned to the labour movement. For men salaries were falling behind those of unionized public servants. They noted that after five years service, recently-organized police and firefighters received annual salaries of $\$ 1,468$, several hundred more than the average for male teachers. Their earnings also compared unfavourably to private sector blue collar workers at the Canadian Pacific Railway Angus Shops, and in some construction trades. As wage differentials disappeared, a middle class life style became less likely. Teachers may have hoped a union would lead to earnings that would secure their status as professionals. Also, their low wages encouraged identification with manual workers even more than they had done before the War. In ABE documents, all explicit comparisons were with unionized manual workers and emphasized the common ground they shared as breadwinners. This underscored male teachers' loss of middle class status. ABE made no such comparisons with women in other occupations, although women teachers' wages compared unfavourably to those of office workers, but instead invoked the example of women who worked for other school boards in Montréal and elsewhere. Catholic lay women's salaries were so low that most probably lived at home. ${ }^{34}$

Australian scholar Andrew Spaull suggests most Canadian teachers refused to join the American Federation of Teachers because, as Anglo-Celtic immigrants, they preferred organization on a British model, and favoured a strong central union of teachers in a province. Montréal's lay Catholic school teachers would have been almost exclusively Canadian-born, with little prior experience of unionism; for them the most visible example was the local labour movement and its strong American ties. Spaull also suggests a latent nationalism in English Canada resisted American influences. By contrast, workers and professionals of all classes in Montréal were forging organizational links across the border. ${ }^{35}$

If teachers elsewhere were reluctant to identify with organized labour because of its militant or radical image, Montréal teachers embraced international unionism. Indeed, by affiliating with the Montréal Trades and Labour Council, Catholic teachers allied themselves with a movement that had long called for educational reforms-reforms the Church hierarchy considered inimical to clerical control of

\footnotetext{
${ }^{33}$ Geoffrey Ewen, " The International Unions and the Workers' Revolt in Québec, 1914-1925," Ph.D. thesis, York University, 1998, 122-53.

${ }^{34} \mathrm{Factum}, 4$; This appears to be the case for most women clerical workers in Canada whose average annual earnings in 1921 was $\$ 785.10$, well above what most lay Catholic women teachers were making in 1919. Graham S.Lowe, "Class, Job, Gender in the Canadian Office," in Laurel Sefton MacDowell and Ian Radforth, eds., Canadian Working Class History. Selected Readings, Toronto, 1991, 416, 426-7; Association du bien-être des instituteurs et des institutrices de Montréal, Manifesteà tous les Professeurs Laiques Catholiques de Montréal, 1920, 7-8; In Chicago few women teachers could survive independently. Murphy, Blackboard Unions, 69.

${ }^{35}$ Spaull, "Fields of Disappointment," 24-5, 27; John Herd Thompson and Stephen J. Randall, Canada and the United States: Ambivalent Allies, Montréal and Kingston, McGillQueen's University Press, 1994, 115.
} 
the school system. Unions advocated a wide range of measures to make public instruction cheaper and more accessible. When the Québec Labour Party, closely controlled by international union leaders, was established in 1899, free and compulsory education became the first plank in its platform: monthly fees were a particular hardship on working class families with several children. In 1904 the Party added establishment of a ministry of education and uniform free textbooks to its list of reforms, so that families moving from one school district to another in the middle of the school year would no longer have to buy new books. In 1910 the Montréal Catholic School Commission eliminated student fees and adopted required texts. In 1916 Montréal Trades and Labour Council leaders not only favoured amalgamation, meaning textbook uniformity over a larger area and an end to the levy of fees by smaller boards, but as well advocated election of school trustees, a direct challenge to clerical control. ${ }^{36}$

Free and compulsory instruction was, unsurprisingly, the most prominent feature of the Québec Labour Party platform. Québec Labourists saw education as key to a more democratic society and a fairer voice in government for workers. The present school system prevented working class electors from making choices based on their class interests. Better public education would lead to more active, informed, and independent political activity. ${ }^{37}$ Education gave workers a means of social mobility. Abbé Phillipe Perrier, a former visiteur ecclésiastique at the Montréal Catholic School Commission, argued that higher levels of public education benefited the working-class and some members of the petite bourgeoisie. Working class representatives before a 1926 commission pleaded passionately for improved access to higher grades. At the time blue collar apprenticeship opportunities were declining, as factories required only a general education and a minimum of skill of most workers. ${ }^{38}$ The decline of skilled labour, the greater importance of unskilled or semi-skilled work, and the rising number of white collar and lower level managerial jobs motivated workers to seek more education for their children.

Of all labour demands, educational reforms most alarmed the clergy. State intervention directly threatened Church control over Catholic schooling. Compul-

\footnotetext{
${ }^{36}$ Urban, Why Teachers Organized, 137; L'Action politique des ouvriers Québécois, 39; Heap, "Urbanisation et éducation," 140; Gagnon, Histoire de la Commission, 92-3, 95.

${ }^{37}$ For the Labor Party's constitution and program see L'Action politique des ouvriers Québécois, 39-41, 46-8. On labourism see Heron, "Labourism and the Canadian Working Class," Labour/Le Travail, 13 (Spring 1984): 45-76; James Naylor, "Ontario Workers and the Decline of Labourism," in Roger Hall et al., eds. Patterns of the Past: Interpreting Ontario's History (Toronto: Dundurn, 1988), 278-300. On French radicalism and its influence on educational reform in Québec see Patrice Dutil, Devil's Advocat: Godfroy Langlois and the politics of Liberal Progressivism in Laurier's Québec (Montréal: Robertson Davies, 1994).

${ }^{37}$ Thérèse Hamel, "L'obligation scolaire au Québec: Enjeu pour le mouvement syndical et agricole," Labour/Le travailleur, 17 (Spring 1986): 89; Johnston, "L'école primaire supérieure," 232-5; Murphy, Blackboard Unions, 16.
} 
sory education was denounced in the harshest terms as "socialiste" and "révolutionnaire." 39

The labour movement sought an egalitarian and democratic society through greater state involvement, whereas the Church upheld a hierarchical view of society in which education and social services were managed by religious authorities. Catholic union promoters described the international unions and the Labour Party as socialist, attacking such measures as old age pensions and state health insurance: the Church considered social welfare its prerogative. The Labour Party advocated replacing private banks with a public financial institution and nationalization or municipalisation of all public utilities; the Church denounced these threats to private property.

It was threats of educational reform as much as fear of socialism that prompted the Québec Church to establish a separate Catholic labour movement to rival secular international unions in the post-War period. The Church provided funds, organizers, buildings, moral support, and a network reaching every parish in the province. Montréal's Catholic teachers were joining international unions just as the Montréal Archdiocese readied a massive campaign against these religiously neutral organizations.

The importance of education for the Church was emphasized in 1918 at the first conference of the growing Catholic labour movement. The leading resolution expressed delegates' opposition to educational reforms, including free, compulsory education and uniform texts. With organized labour divided on these issues, ${ }^{40}$ Catholic unions effectively cancelled out pressure for reform on the provincial government until as late as 1943.

For their part, teachers claimed to be concerned only with wages and working conditions. Like their counterparts in the United States, ABE leaders avoided "inflammatory language." 11 Prominent Catholic public figures, including Eugène Lafontaine and most of Montréal's lay Catholic school commissioners, circulated a petition in 1919 calling for compulsory education, but teachers played no role in this campaign. ${ }^{42}$

The ABE's demands included a salary scale for men and women starting at $\$ 1,200$ to a maximum of $\$ 2,500$; an immediate across-the-board increase of $\$ 400$ dollars, with annual increases thereafter of $\$ 100$; and clear rules and regulations to

${ }^{39}$ André Siegfried, Le Canada. Les deux races, Paris, 1907, 280; Hamel, “L'obligation scolaire," 93, 95; Gagnon, Histoire de la Commission, 92-3.

${ }^{+0} J a c q u e s$ Rouillard, Histoire de la CSN (1921-1981) (Montréal: Boréal Express, 1981), 44; Hamel, "L'obligation scolaire," 85-6; Wendy Johnston, "Contestation et continuité: les comités confessionnels et la gestion des écoles publiques au Québec," Revue d'bistoire de l'Amérique française, 48, 3, hivers 1995, 421.

"Urban, Why Teachers Organized, 139.

${ }^{42}$ This petition was signed by many senior public figures and respectfully submitted to the Catholic committee of the Conseil de l'Instruction publique through the offices of $\mathrm{Mgr}$ Bruchési. ACAM, 871.050 Bureau du surintendant générale (1899-1925) Mgr. Bruchési to $R$. Dandurand, 30 January 1919. 
govern promotions determined by ability, merit, and seniority. Lay-offs were to be determined by length of service, and all firings to be referred to arbitration under a committee of two members of the $\mathrm{ABE}$ and two chosen by the Commission (who would together name a impartial fifth). Objecting to the provincial regulation permitting the Commission to fire teachers without cause, unionists argued that teachers with two years' experience should be fired only for incapacity, insubordination, or immorality. ${ }^{43}$

During the ABE's membership campaign teachers gained support in the labour movement, in the daily press, and in public opinion. For example, the Montréal daily La Patrie encouraged teachers to strike if their demands were not met. For a petition demanding an increase in the property tax to finance better salaries, the $\mathrm{ABE}$ collected over 10,000 signatures, a quarter of them from property owners. Even the Association des propriétaires was prepared to accept a tax increase for this purpose. ${ }^{44}$

From the start, many school commissioners and administrators viewed the $A B E$ with hostility. Teachers from one sub-district were warned away from a first meeting. When the ABE attempted to present demands in October 1919, Commission president Lafontaine refused to meet them without Archbishop Bruchési's approval. On the other hand, the ABE had an advocate on the Central Board: J.M. Perreault, the directeurgénérale des écoles for the Commission from 1908 to 1916, a career administrator who had risen from the ranks of the teachers to the highest position in the school board as it was before 1917. Perreault insisted the ABE was not motivated by a spirit of revolt, that it had made nor threats nor issued any ultimatum, and that there was no question of a strike. ${ }^{45}$

School Commission Chair Eugène Lafontaine explained his objections in detail when he addressed the annual joint meeting of the Central and district school commissioners in the autumn of 1919: ABE salary demands were excessive, and unworkable without a provincially-authorized property tax increase. As to equal pay, Lafontaine argued men who taught younger children in the first three grades were doing women's work and should get women's pay. ${ }^{46} \mathrm{He}$ contended restrictions on hiring and firing would make it impossible to get rid of undesirable teachers. Under such rules a teacher

n'a pas besoin d'être catholique... puisque l'absence de religion ou l'irreligion ne serait pas une cause de renvoi. Un instituteur... pourrait être un agitateur révolutionnaire, un affilié aux sociétés internationales du travail ou autres, un socialiste,

\footnotetext{
${ }^{43}$ See the proposed collective agreement in MLSC Archives, Associations syndicales et autres, Association du bien-être des instituteurs et institutrices de Montréal, Généralité, 1919 à 1920.

"La Patrie, 8, 9 October 1919; Eudore Gobeil to Montréal Catholic School Commission, nd. in MLSCArchives, Associations syndicales et autres, Association du bien-être des instituteurs et institutrices de Montréal, Généralité, 1919 à 1920; Manifeste, 10.

${ }^{45}$ WSU Archives, AFT, Series VI, Box 18, Local 130, Eudore Gobeil to F.G. Stecker, 6March 1920; La Patrie, 29 October 1919; MLSC Archives, Bureau Central, Délibérations, 25 November 1919.

${ }^{46}$ Montréal Catholic School Commission Archives, Assemblée plénière 1918-19, Discours de l'honorable Juge E. Lafontaine, Président du Bureau Central, 18-21.
} 
un anarchiste ou un bolchéviste, il pourrait entretenir, pratiquer et propager n'importe quelle opinion, aussi subversive et aussi destructive de l'ordre de la famille et de la société... et les enseigner et propager en dehors de l'école ou dans l'école même, et prendre part à n'importe quel mouvement contre la religion, l'ordre, le gouvernement et la société...

For Lafontaine, atheists, anarchists, and bolshevists were lumped together with international union members. He suspected a larger agenda behind teachers' demands:

On veut mettre la main sur nos écoles.... Or, l'école est un sanctuaire auguste, divin, à la pureté duquel il faut veiller avec vigilance et fermeté. Mieux vaut mille fois ne pas avoir d'écoles que d'en avoir de mauvaises. ${ }^{47}$

This, he argued, was a question not just of content in public education but of control, and therefore a religious matter. Teachers allied with organized workers would identify with the labourers' "cause," and teach differently. They would abandon the hierarchical view of society upheld by the Church and provincial government leaders in favour of social change as promoted by organized labour. Lafontaine definitively rejected any legitimacy of unionisation for public sector intellectual workers. To perform their duty to society properly, teachers must not submerge their identities in a union. Their real need was for prestige and individuality-qualities associated with professional workers. ${ }^{48}$

Middle class reformers and provincial government leaders insisted teachers were not workers but professionals. When ABE leaders met with premier Lomer Gouin, they had to defend their ties to the labour movement. ${ }^{49} \mathrm{~A}$ high level Montréal Catholic School Commission administrator stated "Les professeurs manqueraient à leur dignité professionnelle, s'ils se mettaient à coudoyer les travailleurs organisés en unions, ${ }^{\text {50 }}$ a clear message for teachers to keep their distance from organized workers. The international unions' parliamentary representative to the provincial government, Gustave Francq, describing his efforts on behalf of the teachers, explained that the school commissioners and most members of the provincial legislature believed "that teachers could not be compared to workers" and made it clear that "in their opinion I was meddling in a question that did not concern Organized Labour and that my interference was resented." ${ }^{\text {1 }}$

In 1919, governments, employers, and the secular and Catholic press ascribed labour militancy to socialist subversion. ABE members were accused of bolshevism -a potent weapon against teachers who aspired to respectability. One school commissioner reproached a teacher that "Vous êtes un bolchéviste: vous êtes entourés par les membres des Unions Internationales qui sont à base de

47Ibid., 27-9.

${ }^{48}$ Ibid., 23; Murphy, Blackboard Unions, 92.

${ }^{49}$ Labor World, 17 January 1920.

${ }^{50}$ Ibid., 6 December 1919.

${ }^{51}$ Trades and Labour Congress of Canada (TLCC), Proceedings of the annual convention, $1921,125$. 
socialisme, d'hommes comme Lacombe, M.P.P., et le Maire Martin. " 52 Ironically, neither figure cited by the commissioner fitted this description. Mayor Médéric Martin was a Liberal Member of Parliament who supported the teachers' right to organize and to bargain collectively; Aurèle Lacombe, president of the Tramway Workers' Union, had recently been elected to the Québec legislature as an independent but immediately sat with the governing Liberals. ABE president Eudore Gobeil declared meetings open to non-members to show teachers had nothing to do with bolshevism or socialism. School principals and trustees countered that no American organization should interfere with Québec education. Facing such arguments, the ABE tried to keep its American Federation of Teachers affiliation a secret. ${ }^{53}$

Catholic clerics were particularly hostile to the ABE. Mgr Bruchési's recently appointed representative, Father René Labelle, declared "que les instituteurs ont mis la Commission au pied du mur." ${ }^{54}$ Another cleric, Abbé J.-O. Maurice, argued that a collective agreement "bouleverseral'ordre établi. ${ }^{.55}$ Addressing a meeting of the ABE, school inspector Abbé Dupuis recommended his auditors show due respect for established authority. ${ }^{56}$ When senior clergy accused teachers of disrespect they spoke with a moral authority beyond their role as employers or high level administrators. To disregard such advice left teachers open to the accusation that they were bad Catholics, and school board officials questioned the faith of teachers who joined a religiously neutral organization. ABE president Eudore Gobeil felt it necessary to declare its members had given "des preuves

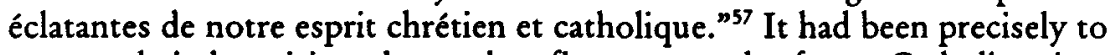
appease clerical suspicions that teachers first attempted to form a Catholic union.

As a practical response to the union's wage demands, Commission President Lafontaine proposed to replace the 238 men who taught boys in the first three grades with women at lower wages, using the savings to pay higher salaries to the few remaining men. With Perreault dissenting, the board passed this motion, but a public outcry forced the board to modify its policy. Rather than being fired at the end of the school year, the laymen would be replaced gradually as they retired. $^{58}$

Administrators and a small group of cooperative employees now sought to undermine ABE salary demands. On 11 November 1919, executive members of

${ }^{52}$ Labor World, 21 August 1920.

${ }^{53}$ La Patrie, 20 October 1919; WSU Archives, AFT, Series VI, Box 18, Local 130, Eudore Gobeil to F.G. Stecker, 6 March 1920.

${ }^{54}$ La Patrie, 29 October 1919.

${ }^{55} \mathrm{MCSC}$ Archives, Association syndical et autres, L'Alliance catholique des professeurs de Montréal, Généralité 1919-1921, Alliance catholique des professeurs de Montréal, Réunion 19 December 1919, 7.

${ }^{56}$ La Patrie, 3 November 1919.

${ }^{57}$ Ibid., 11 December 1919.

${ }^{58}$ MCSC Archives, Bureau Central, Délibérations, 2-3 July 1918,26 November 1918,17 October 1919; La Patrie, 15 October 1919; Factum, 5. 
the Association des Instituteurs de la Circonscription de l' École Normale Jacques-Cartier presented the Commission with a brief earlier rejected by its own membership. Anti-union members of the AICENJC's Comité des intérêts matériels asked for salary increases of $\$ 100$ for men and $\$ 75$ for women, with the smaller bonuses already granted considered part of this amount. This small concession was immediately granted. ${ }^{59}$ The ABE petitioned for an immediate general assembly of the AICENJC, but AICENJC leaders delayed the meeting until the small increment was secure. When it finally met, the AICENJC censored the leaders, forcing them to resign. ${ }^{60}$ The Comité des intérêts matériels then notified the Commission that only the ABE represented the teachers, and disbanded. ${ }^{61}$

Shortly afterwards 125 men and women teachers thanked the Commission for the increase and announced they wanted nothing to do with the ABE. Within days a rival organization, the Alliance catholique des professeurs de Montréal, was formed by the same principals and assistant principals who had lost control of the AICENJC. The Alliance opposed collective bargaining and membership in any professional association not officially recognized by the Commission. No Alliance member could also belong to the $\mathrm{ABE} .{ }^{62} \mathrm{As} \mathrm{ABE}$ president Gobeil later wrote, the Alliance's motto was "Destroy the Bien-être." ${ }^{33}$ At its first open meeting on 5 December, the directeur-secrétaire of the North District Board, assured the audience that they had the support all the district commissioners. The Alliance was quickly and officially endorsed by Archbishop Bruchési. ${ }^{64}$

The provisional committee of the Alliance was officially recognized by the Commission at its next meeting on 10 December 1919, where it asked for higher wages without specifying a scale, declaring its opposition to affiliation with any organization lacking Church support. (An ABE delegation was admitted to this meeting, presumably to give the appearance of equitable treatment.) Responding to ABE demands, Lafontaine asserted the board had done all it could to raise salaries, claiming (dubiously) that under the school act the commission could not

${ }^{59}$ La Patrie, 12 November 1919.

${ }^{60}$ Ibid., 17 November 1919.

${ }^{61}$ MCSC Archives, Bureau Central, Délibérations, 10 December 1919; L'Enseignement primaire, March 1920, 405-6.

${ }^{62}$ MCSC Archives, Bureau Central, Délibérations, 25 November, 10 December 1919; Labor World, 5 June 1920; wSU Archives,AFT, Series VI, Box 18, Local 130, Eudore Gobeil to F.G. Stecker, 6 March 1920; These principles were included in the Lettres Patentes constituant en corporation "Alliance Catboliques des Professeurs de Montréal, Inc," 1922.

${ }^{63}$ WSU Archives, AFT, Series VI, Box 18, Local 130, Monthly Report, December 1919-January 1920.

${ }^{64}$ Archives de l'université Laval, Fonds de l'Alliance des professeurs de Montréal, Assemblée générales 1919-1939, Procès verbaux, 5 December 1919; MCSC Archives, Association syndicals et autres, L'Alliance catholique des professeurs de Montréal, Généralité, 1919-21, 'Les Instituteurs forment une nouvelle association appelée "L'Alliance catholique des Professeurs de Montréal," na, nd; Bureau Central, Délibérations, 22 December 1919. 
sign a collective agreement, and urged the $\mathrm{ABE}$ to present its case instead to the provincial government. ${ }^{65}$

Leaders Gobeil, Fahey and Maltais did indeed present their case to the Provincial Cabinet, asking for legislation to allow the Commission to sign a collective agreement and to permit the Montréal Catholic School Commission to impose an additional tax specifically for higher salaries for lay teachers. Gobeil urged Premier Gouin to see that the teachers received a $\$ 400$ increase before the end of the year. Their reception was mixed. Premier Gouin and his ministers expressed sympathy for decent salaries but grilled Gobeil about the ABE, questioning the absence of official Church support. Gobeil defended the ABE as an independent body composed of Catholics. ${ }^{66}$

$A$ variety of dirty tactics were used against ABE sympathizers. Anonymous letters discredited a school inspector who defended union members. ${ }^{67}$ One school principal admitted trustees had forced him to file a complaint against an ABE member ${ }^{68} \mathrm{By}$ the end of the year threats of dismissal convinced demoralized $\mathrm{ABE}$ supporters to abandon it for the Alliance. Gobeil wrote, "We are having a terrible fight ... most of our members influenced by our Catholic clergy... are frighted [sic] to the utmost to lose their positions." Word of the American Federation of Teachers affiliation leaked out: "We are surrounded by spies and traitors. ${ }^{699}$ Of 400 members at the start of the campaign, only 75 remained in March $19207^{70}$ Union leaders retained the support of most male teachers, however: at the may 1920 regular annual elections of the AICENJC, ABE leaders again won control. ${ }^{71}$

The severest blow came at the end of the 1920 school year. Previously teachers had been rehired automatically each year. For the first time the Commission required individual contracts. All Commission teachers were sent dismissal notices, together with reapplication forms for the following September. In this way 68 active union supporters were let go. ${ }^{72}$

The ABE turned to the labour movement for support. The distant American Federation of Teachers could do little to mobilize public support because of the confidential ABE charter. AFT leaders raised the matter with American Federation

\footnotetext{
${ }^{65}$ MCSC Archives, Bureau Central, Délibérations, 10 December 1919; La Patrie, 11 December 1919.

${ }^{66}$ They presented their case in person and in a written submission, see Factum; for the ministers' reactions see La Patrie, 17, 20 December 1919.

${ }^{67}$ Labor World, 6 December 1919.

${ }^{68}$ La Patrie, 14 November 1919.

69 WSU Archives, AFT, Series VI, Box 18, Local 130, Eudore Gobeil to F.G. Stecker, 25 December 1919.

${ }^{70}$ Ibid., Eudore Gobeil to F.G. Stecker, 6 March 1920.

${ }^{71}$ L'Enseignement primaire, December 1920, 223-6; UQAM Archives, Fonds de l'École Normale Jacques-Cartier, Correspondance avec le Département de l'Instruction Publique, Delage à l'abbé L.A. Desrosiers, 5 July 1921.

${ }^{72}$ Labor World,5 June 1920; MCSC Archives, District Ouest, Délibérations, 29 September 1920.
} 
of Labour President Samuel Gompers in view of the upcoming June AFL convention in Montréal, but Gompers did little on the teachers' behalf. Finally the AFT suggested that organizaed labour in Montréal should assist the ABE. ${ }^{73}$

There was a move at the AFL convention to improve relations with Montréal's ecclesiastical officials. American cleric Father Peter E. Dietz worried that the growing Catholic labout movement would undermine his work to bolster an anti-socialist bloc in the AFL. Gompers and many other AFL union leaders refused to participate in a discussion that involved religious views. Undeterred, Dietz persuaded Bruchési to receive a delegation from the international unions, but the meeting did little to ameliorate Church hostility towards the AFL. ${ }^{74}$

The AFL convention was followed within days by the Semaine sociale on Rerum novarum, meant to bolster the burgeoning Catholic labour movement, and the first major Catholic union offensive against their rivals in Montréal. International unions were attacked directly by $\mathrm{Mgr}$ Bruchési in his opening and closing addresses. There were groups, he said ominously, with dangerous programmes. He expressed concern over resolutions passed at recent labour conventions. He claimed there was "continuellement... des menaces de guerre entre le capital et le travail, entre les patrons et les ouvriers," a reference to the large number of recent strikes. Bruchési was particularly alarmed by work stoppages by municipal workers: "la grève de ceux qui par état, par devoir et par conscience, sont chargé de protéger la vie, la propriété de leurs concitoyens." This was a reference to the 1918 disputes involving police and firefighters, and to a January 1920 strike by waterworks employees that left large parts of Montréal without water for ten days. Bruchési called for legislation with severe penalties to prevent public sector strikes ${ }^{735}$ Since secular labour organizations were responsible for these excesses, he urged their replacement with Catholic unions and hoped the AFL would restrict its activities to the United States. ${ }^{76}$ Bruchési asked Montréal's workers to abandon the AFL. ${ }^{77}$

Bruchési's strongest specific condemnation was reserved for the ABE, which had no right to organize or bargain collectively, let alone to strike. These were legitimate actions only for private sector employees who worked to enrich their employers; teachers worked for the public and the nation. The school Commission could not raise salaries without a tax increase; such legislation would be opposed by property owners. Teachers should resolve the dilemma by placing their trust in those who "protected" them: the school commissioners, directors,

${ }^{73}$ WSU Archives, AFT, Series VI, Box 18, Local 130, FGH to Eudore Gobeil, 16 March 1920 and 9 April 1920.

${ }^{74}$ Mary Harrita Fox, Peter E. Dietz, Labour Priest (Notre Dame, Ind.: University of Notre Dame Press, 1953), 74, 81, 84; Rouillard, Les Syndicats nationaux au Québec, 263-5, 269-70.

${ }^{75}$ Semaine sociale du Canada, Montréal, 1920, 8-9, 206.

${ }^{76}$ Semaine sociale du Canada, 1920, 206.

77This is how his remarks were described in at least one French language newspaper quoted in Labor World, 3 July 1920. The published version of his remarks do not mention this specific formulation but they are not complete. See Semaine sociale du Canada, Montréal, 1920, 202, fn 1 . 
inspectors, bishops, and superintendent who constituted the provincial Conseil de l'instruction publique.

Bruchési asked the school commissioners to forget what had happened and not to fire any teachers; in practice, of course, this meant bowing to his authority. District commissions in fact only rehired teachers willing to sign declarations they would not join an international union. ${ }^{78}$

Into the summer of 1920 , the ABE solicited support from prominent labour leaders, union meetings, and labour clubs tied to the Labor Party but which included unorganized workers. Moral support came from the Metal Trades Council, the bakers' union, and the Club Ouvrier Notre-Dame des Victories. A particularly strong promoter of the ABE was Tramway Union president Aurèle Lacombe, a member of the Provincial Assembly who sat with the governing Liberals. $^{79}$

The Montréal Trades and Labour Council investigated the dismissal of teachers, gathered affidavits to support intimidation charges, and concluded union activity was the sole reason for firings. Delegates considered three courses of action. A general strike proved anathema to Council leaders. A suggestion that the Council open and operate its own schools, like Russian soviets, ${ }^{80}$ was rejected because the Council could not afford such an undertaking. The Fur Workers union proposed children boycott school until the teachers were reinstated. President Maltais welcome this kind of action, and it pleased the city's largest and strongest unions, such as the 2,500 member Sainte-Marie Lodge of the Brotherhood of Railway Carmen at the Canadian Pacific Railway's Angus shops. On the other hand, it was opposed by Gustave Francq, a figure of immense prestige in the Council, who argued a boycott would only hurt children already being turned away from overcrowded schools. Despite a radical reputation, Francq promoted a narrow view of industrial legality and had a history of opposition to unruly strike tactics. In this case he argued trustees were within their rights and that labour should not destroy fundamental structures. Francq swayed the majority to opt to lobby for redress but others, such as the Fur Workers' Albert Foucher in particular, objected that more than mere protest was needed to win public sympathy. ${ }^{81}$

The leadership of the Montréal Trades and Labour Council identified itself closely with the policies of the TLCC and the AFL and was among the least inclined to consider radical or innovative tactics. During the labour revolt Montréal Trades and Labour Council leaders were among the more conservative in Canada playing a key role in limiting the strike wave of May and June 1919. Militancy in Montréal depended more on the strength of individual unions, on

\footnotetext{
${ }^{78}$ Bruchési's remarks on this issue were not published in the Semaine sociale, 1920, 206. There is a full report of his remarks to teachers in Le Devoir, 26 June 1920; Labor World, 9 October 1920.

${ }^{79}$ Labor World, 17,31 January, 14, 28 August 1920; La Patrie, 24 October, 12 November 1919.

${ }^{80}$ Labor World, 7, 21 August 1920.

${ }^{81}$ Labor World, 28 August, 3, 4 September 1920.
} 
formal and informal alliances among labour organizations, and on rank and file pressure than on action taken by the council.

The Council lobbied the Québec government, whose provincial secretary A thanase David referred them back to the school Commission as authority over personnel matters. At the Commission Central Board, board president Lafontaine claimed only district commissions hired and fired, and denied that any teachers were dismissed for union membership rather than incompetence. Council delegates were again stonewalled at the district commissions. Western district commissioners claimed their oath of office prevented them from discussing the matter. The Chair of the Central district admitted fired teachers had not breached any offence punishable with dismissal as stipulated in the school act, then refused to answer questions. The Council returned to the provincial government to request a Royal Commission investigation of the firings. The government refused an inquiry, arbitration, or any right of appeal. Lamely, the Council declared a flagrant violation of right of association. ${ }^{82}$

By the opening of the 1920 school year, about 20 holdouts had signed individual contracts. By August 1921, with hiring completed for the following school year, about $30 \mathrm{ABE}$ members had not been rehired. In the end they were forced to renounce the union or leave Montréal for positions elsewhere. ${ }^{83}$

Some teachers still hoped for a union, and tried to persuade Bruchési to grant a Catholic union in mid-1920, but the Archbishop would not budge. The Alliance ignored a request to help establish the first Catholic labour council in Montreal. This invitation indicated that some Catholic unionists believed teachers should be part of the labour movement. Absorbing the Association des Institutrices, which grudgingly became its Section Feminine, the Alliance remained a company union. Not until 1936 would it move in the direction of effective labour organization. ${ }^{84}$

Ultimately the ABE proved no match for the combined forces of the school Commission and the Church. Destruction of the teachers' union was one of the first setbacks for the international unions and a major blow to the Montréal labour movement. The summer of 1920 marked the beginning of a recession that deprived workers of bargaining power. This was the start of a period of union decline, as union membership dwindled, locals disappeared, most strikes were lost and the majority of organized workers faced wage cuts. Unions entered a period of retrenchment and consolidation, one marked by increasing caution and a reluctance either to organize or engage in new tactics.

${ }^{82}$ MCSC Archives, Bureau Central, Délibérations, 7 September, 4 October 1920; Labor World, 11 September, 6 November 1920, 12 February 1921.

${ }^{83}$ Labor World, 9 October 1920; TLCC Proceedings, 1921, 125; Chartrand, Une certaine alliance, 25.

${ }^{34}$ UQAM, Archives de l'École Normale Jacques Cartier, Correspondance avec divers particuliers et organismes 1919-21, Anonymous mimeographed circular, 2 June 1920; L'Enseignement primaire, September 1921, 41; Chartrand, Une certaine Alliance, 26-45. 